\title{
Optimalisasi Sistem Pelayanan Kesehatan Berjenjang pada Program Kartu Jakarta Sehat
}

\section{Improving Health Care Referral System of Healthy Jakarta Card}

\author{
Fachmi Idris
}

\section{Bagian Ilmu Kesehatan Masyarakat/Ilmu Kedokteran Pencegahan Fakultas Kedokteran Universitas Sriwijaya}

\begin{abstract}
Abstrak
Peningkatan jumlah kunjungan pasien ke rumah sakit pada awal masa pemberlakuan program Kartu Jakarta Sehat (KJS) disebabkan belum optimalnya sistem pelayanan kesehatan berjenjang. PT Asuransi Kesehatan (PT Askes) bersama Dinas Kesehatan DKI Jakarta melakukan berbagai upaya dalam bentuk paket intervensi untuk mengoptimalkan sistem tersebut. Penelitian ini bertujuan untuk mengevaluasi efektivitas paket intervensi PT Askes dan Dinas Kesehatan DKI Jakarta dalam meningkatkan optimilisasi sistem rujukan pelayanan kesehatan. Penelitian ini menggunakan survei potong lintang dengan metode pengambilan sampel acak pada puskesmas di DKI Jakarta terhadap hasil intervensi PT Askes. Hasil intervensi diukur melalui wawancara pada kepala puskesmas atau petugas yang mewakili. Data dianalisis menggunakan tes statistik nonparametrik, yaitu uji Wilcoxon dan regresi Generalized Linear Model. Penelitian dilakukan pada bulan Oktober 2013 hingga Februari 2014. Terdapat perbedaan bermakna pada keempat indikator, terjadinya peningkatan kunjungan peserta KJS dipengaruhi oleh ketersediaan tempat tidur, jumlah peserta KJS terdaftar, intervensi dalam bentuk regulasi, serta persentase pengangguran terbuka. Meskipun ada perbedaan signifikan setelah dikelola PT Askes, hal ini belum cukup membentuk persepsi puskesmas untuk berpendapat bahwa PT Askes memiliki andil dalam mengoptimalkan sistem pelayanan kesehatan berjenjang pada program KJS.

Kata kunci: Dinas Kesehatan Provinsi DKI Jakarta, KJS, pelayanan kesehatan berjenjang
\end{abstract}

\section{Abstract}

Increasing the number of patient visits to the hospital at the beginning of the implementation Healthy Jakarta Card (KJS) program was claimed to be associated with optimization of health care referral system. PT Asuransi Kesehatan (PT Askes) with the DKI Jakarta Department of Health Service made efforts to improve the optimalization that system. This study aimed to evaluate the effectiveness of intervention PT Askes's and DKI Jakarta
Departement Of Health's packages in improving the optimization of health care referral system. This study used a cross sectional survey with a random sampling method in primary health centers in Jakarta related with the result of PT Askes's intervention package. The result of intervention were conducted by interview to the head of the primary health center or officer representing. Data were analyzed with nonparametric statistical tests, using the Wilcoxon test and Generalized Linear Regression Model. The study was conducted in October 2013 until February 2014. There were significant differences between the four indicators, an increase in visits KJS participants are influenced by the availability of beds, number of participants registered KJS, intervention in the regulation, and the percentage of open unemployment. Although there were significant differences after managed by PT Askes, these efforts were not enough to make primary health centers perception that PTAskes has contributed to the optimization of health care referral system in KJS program .

Keywords: Dinas Kesehatan Provinsi DKI Jakarta, KJS, health care referral system

\section{Pendahuluan}

Kartu Jakarta Sehat (KJS) mulai diberlakukan Pemerintah Provinsi DKI Jakarta sejak bulan November 2012. Hingga triwulan pertama tahun 2013, pengelolaannya masih dilakukan secara mandiri oleh Pemerintah Provinsi DKI Jakarta. Pada tanggal 1 April 2013, sebagian ruang lingkup pengelolaannya dipercayakan kepada PT Askes.

Salah satu permasalahan pada awal masa berlakunya KJS adalah meningkatnya kunjungan peserta KJS ke

Korespondensi: Fachmi Idris, Bagian Ilmu Kesehatan Masyarakat/Ilmu Kedokteran Pencegahan FK Universitas Sriwijaya, Jl. Madang KM 3,5 Palembang, Hp.08129009527, e-mail:fachmi_id@yahoo.com 
rumah sakit yang mengakibatkan rumah sakit tidak mampu melayani dan terpaksa menolak peserta. Pada awal pelaksanaan program KJS, Gubernur DKI Jakarta gencar membagikan kartu kepada masyarakat, namun nampaknya luput memberitahu masyarakat mengenai sistem pelayanan kesehatan berjenjang yang menjadi salah satu persyaratannya. Akibatnya, sistem pelayanan kesehatan berjenjang belum optimal dilaksanakan karena masyarakat merasa bisa langsung berobat ke rumah sakit tanpa membawa surat rujukan dari puskesmas. ${ }^{1}$

Permasalahan ini membutuhkan intervensi khusus. Paket intervensi khusus ini dalam program KJS dilakukan tidak hanya oleh PT Askes, namun juga oleh pemerintah provinsi melalui dinas kesehatan atau Unit Pengelola Jaminan Kesehatan Daerah (UP Jamkesda), serta Dewan Perwakilan Rakyat DKI Jakarta (DPRD). Untuk mempermudah penyebutan, intervensi ini dinamakan 'Paket Intervensi Pola Jaminan Kesehatan Nasional (JKN)'.

Secara rinci, paket intervensi yang dikelola PT Askes di dalam Paket Intervensi Pola JKN ada sepuluh aktivitas, yaitu pertemuan dengan puskesmas, perjanjian kerjasama dengan Pemerintah Provinsi DKI Jakarta, sosialisasi KJS, penerapan konsep pelayanan kesehatan berjenjang, penanganan keluhan peserta KJS, pendaftaran peserta KJS di puskesmas, penambahan pegawai untuk program KJS, pendidikan dan pelatihan untuk petugas puskesmas, pembuatan aplikasi pelayanan kesehatan (Pcare), dan monitoring dan evaluasi.

DPRD Provinsi DKI Jakarta juga melakukan paket intervensi. ${ }^{2,3}$ Paket intervensi yang dijalankan DPRD di dalam Paket Intervensi Pola JKN ada enam aktivitas, yaitu kebijakan dan kegiatan yang mendukung kebutuhan puskesmas, memprioritaskan program-program pelayanan publik yang sesuai kebutuhan dan aspirasi masyarakat, mengesahkan peraturan daerah yang mendukung pelaksanaan KJS, mengawasi pelaksanaan KJS dengan efektif, menyediakan anggaran yang cukup untuk mendukung pelaksanaan KJS, dan membantu penyelesaian masalah KJS.

Pemerintah Provinsi DKI Jakarta yang menginisiasi program KJS pada tanggal 1 November 2012, selanjutnya menjalankan Paket Intervensi Pola JKN dan melakukan intervensi program KJS dalam bentuk paket intervensi bersama bersama PT Askes. ${ }^{4,5}$ Paket intervensi ini mencakup sepuluh aktivitas, yaitu terbitnya peraturan daerah yang mendukung KJS, dimilikinya sistem monitoring KJS yang baik, terfasilitasinya pertemuan kepala puskesmas se-DKI Jakarta untuk membahas permasalahan KJS, terfasilitasinya pelatihan bagi petugas puskesmas terkait program KJS, tersedianya tenaga medis untuk mendukung program KJS, adanya tingkat perhatian pada kualitas pelayanan KJS, dikembangkannya program-program yang sesuai dengan kebutuhan dan aspirasi masyarakat, keterbukaan dalam pengelolaan keuangan KJS, kesesuaian peraturan daerah tentang KJS dengan peraturan yang lebih tinggi, dan dipertanggungjawabkannya program KJS kepada DPRD.

Paket intervensi pola JKN dalam bentuk paket intervensi dari PT Askes, dinas kesehatan dan DPRD DKI Jakarta, secara keseluruhan berjumlah 26 aktivitas. Studi ini bertujuan untuk mengevaluasi efektivitas paket intervensi PT Askes pada program KJS dalam mendorong penerapan sistem pelayanan kesehatan berjenjang yang diukur melalui rata-rata jumlah kunjungan peserta ke puskesmas. Selain itu, studi ini juga bertujuan untuk mengevaluasi percepatan pendaftaran peserta KJS, layanan kesehatan berjenjang, percepatan sambungan internet di puskesmas, dan peningkatan kepuasan puskesmas terhadap penanganan keluhan setelah KJS dikelola oleh PT Askes. Penelitian ini juga bermanfaat untuk penguatan keempat fungsi tersebut dalam menyambut program JKN yang diberlakukan mulai tanggal 1 Januari 2014.

\section{Metode}

Intervensi untuk mengoptimalisasi sistem pelayanan kesehatan berjenjang dilaksanakan oleh berbagai pihak, yaitu PT Askes, DPRD, dan Pemerintah Provinsi DKI Jakarta. Untuk mengukur tingkat keberhasilannya, responden (kepala puskesmas atau petugas yang mewakili) diminta penilaiannya tentang peran dari masing-masing pihak untuk kemudian diukur hubungannya dengan ratarata jumlah kunjungan peserta ke puskesmas.

Survei dengan desain potong lintang dilakukan pada 250 puskesmas di kecamatan dan kelurahan di DKI Jakarta pada bulan November hingga Desember 2013. Sampel dipilih secara acak melalui daftar puskesmas di DKI Jakarta yang berjumlah 340. Sampel juga dipilih secara proporsional terhadap jumlah puskesmas di setiap kota. Petugas lapangan mewawancarai responden menggunakan kuesioner sebagai panduan. Responden adalah kepala puskesmas dengan kriteria memahami penerapan program KJS di puskesmas. Jika kriteria ini tidak bisa dipenuhi karena berbagai alasan, responden dapat ditemani staf puskesmas yang memenuhi kriteria tersebut.

Variabel terikat adalah paket intervensi PT Askes yang diukur dengan rata-rata jumlah kunjungan, rata-rata jumlah peserta KJS yang terdaftar, status pemasangan internet, serta tingkat kepuasan puskesmas terhadap pelayanan keluhan peserta yang dilakukan PT Askes. Variabel tingkat kepuasan berskala likert 1 sampai dengan 5. Kode 1 mewakili persepsi 'sangat tidak puas' dan kode 5 mewakili persepsi 'sangat puas'. Dengan pendekatan top-two-boxes, tingkat kepuasan diperoleh melalui persentase jawaban 'puas' diwakili kode 4 dan 'sangat puas' diwakili kode 5, dibandingkan seluruh jawaban. 
Variabel bebas terdiri persentase peserta KJS berusia di atas 50 tahun yang terdaftar di puskesmas, jumlah tempat tidur, pelayanan yang dapat diberikan puskesmas, serta persepsi puskesmas terhadap peran PT Askes, pemerintah provinsi dan DPRD terhadap kelancaran program KJS, proporsi penduduk miskin, rasio ketersediaan puskesmas per 100.000 penduduk, persentase pengangguran terbuka, dan proporsi penduduk yang buta huruf.

Analisis dilakukan secara deskriptif untuk melihat profil responden dan gambaran pencapaian keempat indikator sebelum dan sesudah intervensi PT Askes, pengujian beda nilai tengah dua populasi melalui uji statistik nonparametrik Wilcoxon, serta regresi Generalized Linear Model. Analisis ini dipilih karena memberikan keringanan pada beberapa asumsi regresi linier seperti asumsi normalitas dan korelasi antar varibel bebas.

\section{Hasil}

Dari 250 puskesmas yang disasar, tim lapangan berhasil mewawancarai 242 puskesmas dengan tingkat keberhasilan 97\%. Kendala dalam pengumpulan data di lapangan di antaranya, puskesmas tidak punya waktu untuk menyiapkan data yang dibutuhkan untuk survei, puskesmas menolak diwawancarai, dan tim lapangan perlu melakukan lebih dari satu kunjungan untuk memperoleh data yang lengkap.

Dari hasil survei, responden di puskesmas memiliki karakteristik berusia rata-rata 36,5 tahun, mayoritas berjenis kelamin perempuan dan berpendidikan sarjana. Sebagian besar puskesmas responden berlokasi di Jakarta Barat (Tabel 1).

Terdapat kecenderungan peningkatan pendaftaran peserta KJS secara cukup tajam sejak periode 1 April 2013, sejak bergabungnya PT Askes ke dalam pengelolaan KJS. Di saat yang sama, jumlah kunjungan peserta KJS ke puskesmas terlihat stabil meskipun dari bulan Agustus sampai September terdapat sedikit kenaikan.

Gambar 1 menunjukkan ada peningkatan jumlah peserta terdaftar setelah KJS dikelola PT Askes, meskipun terdapat keanehan karena data jumlah kunjungan ke puskesmas cenderung stabil. Hal ini dapat disebabkan permasalahan pencatatan data di puskesmas, sebagaimana temuan pewawancara di lapangan. Sedangkan data PT Askes menunjukkan kecenderungan yang terus meningkat sebagaimana ditunjukkan pada Tabel 2.

Perkembangan ketersediaan sambungan internet di puskesmas serta kepuasan puskesmas terhadap penanganan keluhan peserta KJS dirangkum dalam Gambar 2. Sebelum PT Askes mengelola KJS, rata-rata peningkatan jumlah puskesmas yang tersambung internet adalah 3\% per bulan. Setelah PT Askes mengelola KJS, rata-rata peningkatannya menjadi 5\% per bulan.

Kepuasan puskesmas terhadap penanganan keluhan peserta KJS diukur dengan metode top-two-boxes. Pada
Tabel 1. Profil Responden

\begin{tabular}{lll}
\hline Variabel & Kategori & Persentase (\%) \\
\hline Usia (tahun) & $<25$ & 9,5 \\
& $25-35$ & 39,8 \\
& $35-45$ & 18,3 \\
& $45-55$ & 29,9 \\
Jenis kelamin & $>55$ & 2,5 \\
Pendidikan & Laki-laki & 43,2 \\
& Perempuan & 56,9 \\
& $<$ SMU & 2,1 \\
Lama bekerja di puskesmas (tahun) & $<5$ & 37,3 \\
& SMU & 18,7 \\
& Diploma & 41,9 \\
& S1 & 43,6 \\
Kota & $10-15$ & 25,3 \\
& $15-20$ & 8,3 \\
& $>20$ & 5,4 \\
& Jakarta Barat & 17,4 \\
& Jakarta Pusat & 28,2 \\
& Jakarta Selatan & 14,1 \\
& Jakarta Timur & 27,4 \\
& Jakarta Utara & 22,4 \\
& & 7,9 \\
\hline
\end{tabular}

awal penerapan KJS di bulan November 2012, tingkat kepuasannya adalah $30 \%$. Kepuasan ini terus meningkat hingga mencapai 82\% pada bulan September 2013.

Karena variabel terikat tidak menyebar normal (bahkan setelah transformasi logaritma dan akar), pengujian kemaknaan dilakukan melalui uji nonparametrik yaitu Uji Wilcoxon. Uji ini dilakukan untuk melihat apakah terdapat perbedaan yang bermakna pada variabel terikat pada masa sebelum dan sesudah PT Askes mengelola KJS.

Seluruh variabel penelitian mengalami peningkatan yang signifikan setelah pengelolaan KJS oleh PT Askes. Melalui uji peringkat bertanda dan uji tanda Wilcoxon, seluruh variabel penelitian memiliki nilai $\mathrm{p}$ di bawah tingkat kesalahan yang dipersyaratkan $(5 \%)$. Hal ini mengindikasikan terjadi peningkatan jumlah pendaftaran peserta KJS, jumlah kunjungan ke puskesmas, jumlah puskesmas yang memiliki sambungan internet, dan tingkat kepuasan puskesmas terhadap penanganan keluhan pada masa PT Askes mengelola KJS. Penjelasan lebih lanjut dapat dilihat di Tabel 3.

Tabel 4 menunjukkan hubungan antara kinerja PT Askes, DPRD serta Pemerintah Provinsi DKI Jakarta terhadap kunjungan peserta KJS ke puskesmas. Untuk mengurangi dampak autokorelasi antara variabel penjelas kinerja, dilakukan analisis faktor yang berhasil mengurangi variabel penjelas kinerja PT Askes dari 10 menjadi 5, DPRD dari 6 menjadi 3, dan Pemerintah Provinsi DKI Jakarta dari 10 menjadi 5.

Mengingat data rata-rata kunjungan ke puskesmas tidak menyebar normal, dilakukan analisis regresi Generalized Linear Model yang dapat mengabaikan sebaran data. Sebanyak 191 data dianalisis dan hasilnya 


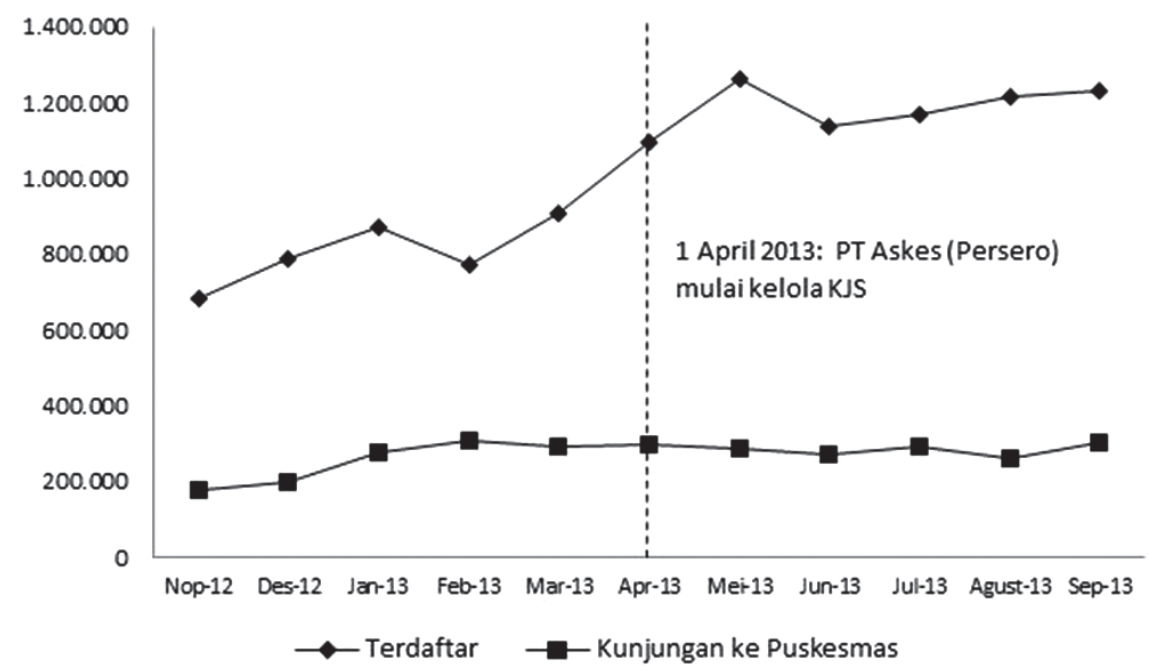

Gambar 1. Perkembangan Peserta Terdaftar dan Kunjungan ke Puskesmas

Tabel 2. Jumlah Peserta Kartu Jakarta Sehat Terdaftar

\begin{tabular}{ll}
\hline Bulan & Jumlah \\
\hline April & 1.985 .780 \\
Mei & 2.159 .583 \\
Juni & 2.680 .802 \\
Juli & 2.867 .737 \\
Agustus & 3.054 .173 \\
September & 3.220 .637 \\
\hline
\end{tabular}

Sumber: Laporan PT Askes

menunjukkan pihak yang memiliki peran dalam mendorong peserta KJS untuk mematuhi pelayanan kesehatan berjenjang melalui puskesmas adalah PT Askes, dalam hal ini melalui kegiatan tatap muka. Untuk Pemerintah Provinsi DKI Jakarta, melalui regulasi yang dihasilkannya. Namun, keduanya memiliki dampak yang berlawanan karena kegiatan tatap muka yang dilakukan PT Askes berhubungan dengan menurunnya tingkat kunjungan ke puskesmas, sementara regulasi yang dibuat Pemerintah Provinsi DKI memiliki hubungan sebaliknya. Hasil analisis identik dengan hasil ordinary least square dengan nilai $R$-square $49,1 \%$.

Variabel penjelas lainnya yang berasosiasi dengan meningkatnya kunjungan peserta KJS ke puskesmas adalah ketersediaan tempat tidur, log jumlah peserta per puskesmas, serta rasio pengangguran di kota setempat. Hal ini menunjukkan bahwa peserta KJS mengunjungi puskesmas karena fasilitas yang disediakannya, serta karena tidak memiliki pekerjaan. Variabel yang disebutkan terakhir memang memiliki asosiasi negatif terhadap tingkat kesehatan yang menyebabkan kelompok masyarakat pengangguran cenderung membutuhkan layanan kesehatan.

\section{Pembahasan}

Hasil analisis regresi Generalized Linear Model me- nunjukkan bahwa optimalisasi sistem pelayanan kesehatan berjenjang salah satunya dipengaruhi oleh ketersediaan jumlah tempat tidur di puskesmas. Hal ini konsisten dengan penelitian lainnya, upaya meningkatkan mutu pelayanan kesehatan berpengaruh pada akses masyarakat kepada fasilitas kesehatan primer. ${ }^{6}$

Dari sisi permintaan pelayanan kesehatan, kondisi kesehatan peserta KJS juga menentukan jumlah kunjungan ke puskesmas. Semakin tinggi persentase peserta berusia di atas 50 tahun yang terdaftar di puskesmas, jumlah kunjungan cenderung meningkat. Peneliti lain juga menemukan hubungan antara banyaknya peserta usia lanjut dan peningkatan kunjungan di puskesmas sebagai akibat status kesehatan mereka yang semakin menurun. ${ }^{7-9}$

Studi ini tidak saja menganalisis faktor-faktor pada tingkat puskesmas, melainkan juga pada tingkat kota. Berdasarkan hasil analisis Generalized Linear Model, tampak bahwa persentase penduduk miskin di suatu kota berpengaruh positif terhadap jumlah kunjungan ke puskesmas. Hubungan antara kemiskinan dengan kesehatan memang telah banyak dibahas penelitian lain. Orang miskin cenderung memiliki status kesehatan yang buruk sehingga membutuhkan layanan kesehatan. ${ }^{10-12}$ Namun, orang miskin memiliki hambatan finansial untuk memperoleh layanan kesehatan sehingga program asuransi kesehatan (semacam KJS) mampu meningkatkan akses mereka ke fasilitas kesehatan primer. ${ }^{13}$

Selain kemiskinan, faktor di tingkat kota yang juga berpengaruh positif terhadap jumlah kunjungan ke puskesmas adalah persentase pengangguran. Beberapa studi mengasosiasikan pengangguran dengan status kesehatan yang buruk. ${ }^{14-16}$ Ada dua mekanisme yang menjelaskan hubungan antara pengangguran dengan rendahnya tingkat kesehatan, yaitu kecenderungan menunda pelayanan kesehatan karena alasan biaya dan kesulitan 


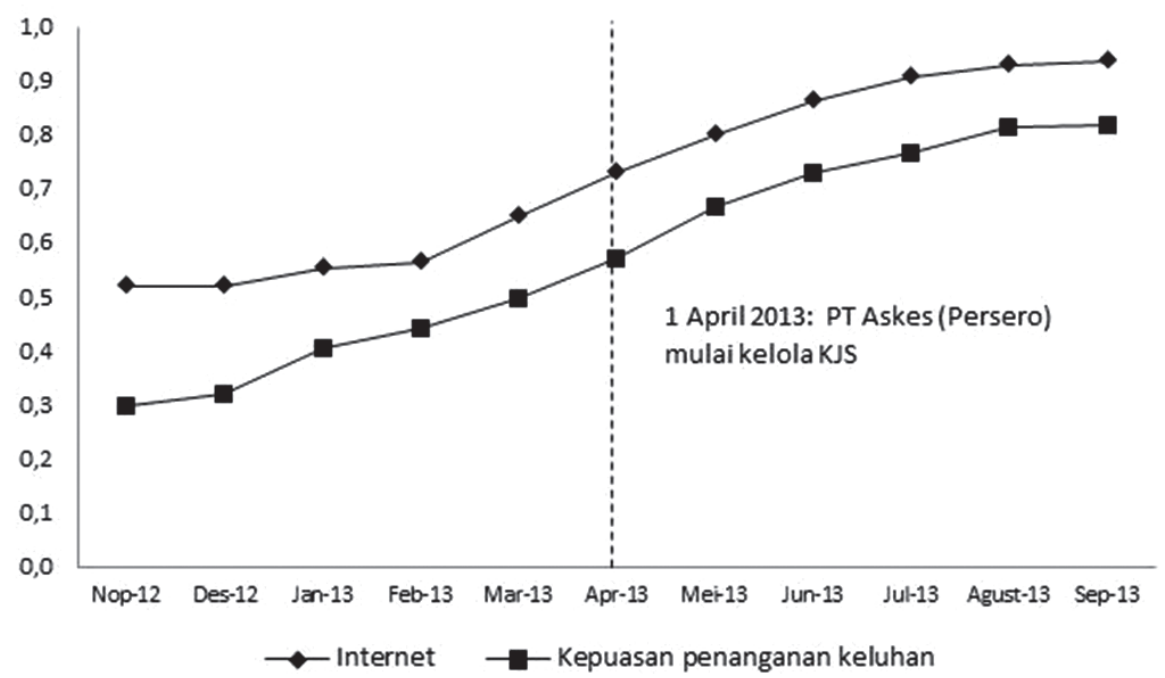

Gambar 2. Perkembangan Internet dan Kepuasan Puskesmas dalam Penanganan Keluhan yang Dilakukan PT Askes

Tabel 3. Hasil Uji Wilcoxon

\begin{tabular}{llll}
\hline Variabel & Hipotesis & Nilai p & Keterangan \\
\hline Pendaftaran & $\mathrm{H}_{\mathrm{a}}: \mathrm{D}_{1} \neq \mathrm{D}_{2}$ & $0,000^{*}$ & Bermakna \\
& $\mathrm{H}_{\mathrm{a}}:$ median $\mathrm{D}_{1}<$ median $\mathrm{D}_{2}$ & $0,000^{*}$ & Bermakna \\
Kunjungan ke puskesmas & $\mathrm{H}_{\mathrm{a}}: \mathrm{P}_{1} \neq \mathrm{P}_{2}$ & $0,000^{*}$ & Bermakna \\
& $\mathrm{H}_{\mathrm{a}}:$ median $\mathrm{P}_{1}<$ median $\mathrm{P}_{2}$ & $0,048^{*}$ & Bermakna \\
Sambungan internet & $\mathrm{H}_{\mathrm{a}}: \mathrm{I}_{1} \neq \mathrm{I}_{2}$ & $0,000^{*}$ & Bermakna \\
& $\mathrm{H}_{\mathrm{a}}:$ median $\mathrm{K}_{1}<$ median $\mathrm{K}_{2}$ & $0,000^{*}$ & Bermakna \\
Kepuasan keluhan & $\mathrm{H}_{\mathrm{a}}: \mathrm{K}_{1} \neq \mathrm{K}_{2}$ & $0,000^{*}$ & Bermakna \\
& $\mathrm{H}_{\mathrm{a}}:$ median $\mathrm{K}_{1}<$ median $\mathrm{K}_{2}$ & $0,000^{*}$ & Bermakna \\
\hline
\end{tabular}

*Uji Wilcoxon, Ket: $a=5 \%$

memperoleh akses kepada pelayanan kesehatan jika dibandingkan bukan pengangguran. ${ }^{17}$ Tampaknya hal yang sama juga terjadi pada pengangguran di DKI Jakarta.

Meskipun hasil uji Wilcoxon menunjukkan ada peningkatan signifikan jumlah kunjungan peserta KJS ke puskesmas setelah pengelolaan KJS oleh PT Askes, hasil Generalized Linear Model menunjukkan persepsi puskesmas terhadap peran PT Askes justru mengurangi angka kunjungan peserta KJS ke puskesmas. Kontradiksi ini menunjukkan kemungkinan tidak efektifnya intervensi yang dilakukan PT Askes untuk membentuk persepsi puskesmas di DKI Jakarta dalam upaya optimalisasi sistem pelayanan kesehatan berjenjang.

Kemungkinan penyebabnya adalah materi yang disampaikan oleh PT Askes dalam beberapa pertemuan dengan puskesmas tidak secara spesifik membahas tentang sistem pelayanan kesehatan berjenjang, melainkan lebih bersifat umum. Hal ini berbeda dengan materi yang disampaikan oleh Dinas Kesehatan Provinsi DKI Jakarta yang secara spesifik menjelaskan tentang sistem pelayanan kesehatan berjenjang. Bisa saja hal ini yang menyebabkan persepsi puskesmas terhadap peran PT
Askes dalam peningkatan sistem pelayanan kesehatan berjenjang menjadi kurang terbentuk.

Dalam praktiknya, PT Askes telah berulang kali menyampaikan pentingnya sistem rujukan dipatuhi untuk menghindari penumpukan pasien di rumah sakit. Dalam setiap kesempatan sosialisasi atau evaluasi dengan pihak-pihak terkait seperti dinas kesehatan serta fasilitas kesehatan, pentingnya konsep gate keeper puskesmas selalu tercatat dalam notulen atau materi pertemuan. Kenyataan bahwa puskesmas tidak memiliki persepsi bahwa peningkatan kunjungan peserta KJS ke puskesmas merupakan andil PT Askes menjadi masukan untuk mengevaluasi metode sosialisasinya kepada fasilitas kesehatan.

Hasil analisis Generalized Linear Model juga menunjukkan puskesmas memiliki persepsi bahwa regulasi yang dihasilkan Pemerintah Provinsi DKI Jakarta berdampak pada peningkatan jumlah kunjungan peserta KJS ke puskesmas. ${ }^{18}$ Dinas kesehatan bersama PT Askes sering bersama-sama menyampaikan pentingnya layanan kesehatan berjenjang kepada puskesmas pada berbagai kesempatan. Namun yang membedakan kedua instansi ini adalah posisinya di hadapan puskesmas. PT Askes 
Idris, Optimalisasi Sistem Pelayanan Kesehatan Berjenjang Program pada Kartu Jakarta Sehat

Tabel 4. Hubungan antara Rata-rata Jumlah Kunjungan Peserta KJS ke Puskesmas dengan Variabel Lainnya

\begin{tabular}{|c|c|c|c|}
\hline Variabel & Koefisien Regresi & Standar Error & $\mathbf{P}>|\mathbf{z}|$ \\
\hline Persentase peserta usia $>50$ tahun & $-0,34$ & 0,77 & 0,661 \\
\hline Jumlah tempat tidur & 0,10 & 0,02 & 0,000 \\
\hline $\log$ (peserta) & 0,13 & 0,04 & 0,001 \\
\hline \multicolumn{4}{|l|}{ Layanan di Puskesmas } \\
\hline Bedah, urologi, mata & 0,08 & 0,08 & 0,370 \\
\hline Diagnosa fungsional & 0,11 & 0,12 & 0,351 \\
\hline Spesialis \& laboratorium & 0,22 & 0,13 & 0,075 \\
\hline Trauma \& THT & 0,11 & 0,12 & 0,357 \\
\hline Umum \& gigi & 0,06 & 0,18 & 0,734 \\
\hline Psikoterapi & 0,32 & 0,27 & 0,226 \\
\hline Vaksinasi & 0,68 & 0,59 & 0,255 \\
\hline \multicolumn{4}{|l|}{ Peran PT Askes } \\
\hline Tatap muka & $-0,24$ & 0,11 & 0,029 \\
\hline Keluhan \& sumber daya manusia & $-0,14$ & 0,13 & 0,276 \\
\hline Administrasi & $-0,19$ & 0,16 & 0,227 \\
\hline Konsep rujukan berjenjang \& aplikasi & 0,10 & 0,16 & 0,529 \\
\hline \multicolumn{4}{|l|}{ Peran DPRD } \\
\hline Dukungan moral & $-0,09$ & 0,11 & 0,420 \\
\hline Monitoring dan evaluasi & 0,24 & 0,13 & 0,068 \\
\hline Regulasi \& anggaran & 0,18 & 0,16 & 0,258 \\
\hline \multicolumn{4}{|l|}{ Peran Pemerintah Provinsi DKI Jakarta } \\
\hline Regulasi & 0,31 & 0,14 & 0,030 \\
\hline Profesionalisme & 0,13 & 0,16 & 0,397 \\
\hline Pelayanan & $-0,11$ & 0,13 & 0,358 \\
\hline Sumber daya manusia & $-0,03$ & 0,12 & 0,813 \\
\hline Program & $-0,01$ & 0,23 & 0,960 \\
\hline \multicolumn{4}{|l|}{ Faktor Kota } \\
\hline Rasio puskesmas per 100.000 penduduk & $-0,02$ & 0,19 & 0,897 \\
\hline Rasio kemiskinan & $-0,47$ & 0,26 & 0,072 \\
\hline Rasio pengangguran & 0,63 & 0,16 & 0,000 \\
\hline Rasio buta huruf & 0,09 & 0,05 & 0,096 \\
\hline Konstanta & 0,43 & 1,54 & 0,782 \\
\hline
\end{tabular}

Ket: $\alpha=5 \%$

adalah mitra puskesmas, sementara dinas kesehatan adalah atasan puskesmas. Dalam menjalankan fungsinya sebagai atasan, dinas kesehatan dapat memberikan perintah atau instruksi yang langsung ditindaklanjuti oleh puskesmas. Berbeda dengan PT Askes yang hanya dapat menyampaikan himbauan atau masukan terhadap puskesmas.

\section{Kesimpulan}

Intervensi yang dilakukan dinas kesehatan melalui regulasi bermakna menumbuhkan persepsi puskesmas terhadap peran Pemerintah Provinsi DKI Jakarta dalam mendorong optimalisasi sistem pelayanan kesehatan berjenjang. Hal ini dapat disebabkan posisi dinas kesehatan yang merupakan atasan langsung dari puskesmas sehingga segala aturan yang dikeluarkannya langsung berdampak pada kinerja puskesmas. Sementara intervensi yang dilakukan PT Askes meskipun telah banyak dilakukan namun tidak cukup membentuk persepsi puskesmas terhadap peran PT Askes dalam mendorong sistem pelayanan berjenjang dalam program KJS.

Setelah KJS dikelola PT Askes, ada peningkatan pada empat indikator, yaitu percepatan pendaftaran peserta KJS, layanan kesehatan berjenjang, percepatan sambungan internet di puskesmas, peningkatan kepuasan puskesmas terhadap penanganan keluhan. Meningkatnya kunjungan peserta KJS ke puskesmas setelah pengelolaan KJS oleh PT Askes masih dipengaruhi oleh faktor permintaan dan penawaran pelayanan kesehatan. Dari sisi permintaan, persentase peserta berusia lanjut yang terdaftar di puskesmas, serta persentase orang miskin dan pengangguran di tingkat kota memiliki pengaruh yang signifikan. Sementara dari sisi penawaran, ketersediaan pelayanan dokter spesialis, laboratorium, serta pelayanan rawat inap mendorong peserta KJS untuk mendatangi puskesmas.

\section{Saran}

Pengalaman penerapan sistem pelayanan kesehatan berjenjang pada awal pelaksanaan program KJS mem- 
berikan pelajaran berharga untuk penerapan sistem serupa pada program JKN. Selain meningkatkan sarana dan jenis layanan yang dapat diberikan puskesmas, PT Askes (sekarang BPJS Kesehatan) dapat mendorong optimalisasi sistem pelayanan berjenjang melalui kerjasama yang saling menguntungkan bersama dinas kesehatan. PT Askes menyediakan data dan informasi berharga tentang pelaksanaan program KJS sehari-hari di lapangan. Dinas kesehatan memanfaatkan data dan informasi tersebut untuk membuat regulasi yang dapat mengintervensi fasilitas kesehatan.

\section{Daftar Pustaka}

1. PT Askes (Persero) Divisi Regional IV. Laporan pelaksanaan program Kartu Jakarta Sehat (KJS) Periode 1 s/d 31 Juli 2013. Jakarta: PT Askes; 2013.

2. Pemerintah Republik Indonesia. Undang-Undang Nomor 27/2009 tentang Majelis Permusyawaratan Rakyat, Dewan Perwakilan Rakyat, Dewan Perwakilan Daerah, dan Dewan Perwakilan Rakyat Daerah. Jakarta: Lembaga Negara Republik Indonesia; 2009.

3. Gaffar A. Politik Indonesia: transisi menuju demokrasi. Yogjakarta: Pustaka Pelajar; 2000.

4. Bank Dunia. Mengoptimalkan kontribusi desentralisasi bagi pembangunan: metodologi kerangka kerja pengukuran kinerja pemerintah daerah (LGPM). Jakarta: World Bank Indonesia; 2008.

5. Dwiyanto A. Penilaian kinerja organisasi publik. Makalah dalam Seminar Sehari: Kinerja Organisasi Sektor Publik, Kebijakan dan Penerapannya. Jogjakarta: Fisipol UGM; 1995.

6. Dick B, Ferguson J, Chandra-Mouli V, Brabin L, Chatterjee S, Ross DA. Review of the evidence for interventions to increase young people's use of health services in developing countries. Geneva: WHO Technical Report Series; No. 938; 2006.

7. Bowser D, Mahal A. The economic burden of illness and health system implications. Health Policy. 2011;100:159-66.

8. Galarraga O, Sosa-Rubi S, Salinas-Rodriguez A, Sesmas-Vazquez S.
Health insurance for the poor: impact on catastrophic and out-of-pocket health expenditures in Mexico. Health Economics. 2010;11:437-47.

9. Xu K, Evans DB, Kawabata K, Aguilar Rivera AM, Musgrov P, Evans T. Household catastrophic health expenditure: a multicountry analysis. The Lancet. 2006; 362: 111-7.

10. Satyanarayana K, Srivastava S. Poverty, health \& intellectual property rights with special reference to India. Indian Journal of Medical Research. 2007; 126: 390-406.

11. Montgomery M. Urban poverty and health in developing countries. Population Reference Bureau. 2009; 64 (2).

12. Agarwal S, Satyavada A, Kaushik S, Kumar R. Urbanization, urban poverty and health of the urban poor: status, challenges and the way forward. Demography India. 2007; 36 (1): 121-34.

13. Falkingham J. Poverty, out-of-pocket payments and access to health care: evidence from Tajikistan. Social Science \& Medicine 2004;58:247-58.

14. Suhrcke M, Stuckler D. Will the recession be bad for our health? It depends. Social Science \& Medicine. 2012;74:647-653.

15. Muntaner C, Solar O, Vanroelen C, Martinez JM, Vergara M, Santana V. Unemployment, informal work, precarious employment, child labor, slavery, and health inequalities: pathways and mechanisms. International Journal of Health Services. 2010; 40(2): 281-95.

16. Puig-Barrachina V, Malmusi D, Martinez JM, Benach J. Monitoring social determinants of health inequalities: the impact of unemployment among vurnerable groups. International Journal of Health Services. 2011; 41(3): 459-82.

17. Pharr JR, Moonie S, Bungum TJ. The impact of unemployment on mental and physical health, access to health care and health risk behaviours. ISRN Public Health [internet]. 2012 [cited 2015 Apr 5]; about 7 page. Available from: http://digitalscholarship.unlv.edu/cgi/view content.cgi? article $=1082 \&$ context $=$ community_health_sciences_fac_articles.

18. Dinas Kesehatan Pemerintah Provinsi DKI Jakarta. Surat edaran nomor 41/SE/2013 perihal pembiayaan program KJS di puskesmas tanggal 14 Mei 2013. Jakarta: Dinas Kesehatan Pemerintah Provinsi DKI Jakarta 2013. 